\title{
From Political Islam to Conservative Democracy: The Case of the Justice and Development Party in Turkey
}

\section{Ergun Özbudun}

To cite this article: Ergun Özbudun (2006) From Political Islam to Conservative Democracy: The Case of the Justice and Development Party in Turkey, South European Society \& Politics, 11:3-4, 543-557, DOI: $10.1080 / 13608740600856561$

To link to this article: https://doi.org/10.1080/13608740600856561

Published online: 02 Dec 2009.

Submit your article to this journal $\square$

Џll Article views: 2488

Citing articles: 37 View citing articles $\square$ 


\section{From Political Islam to Conservative Democracy: The Case of the Justice and Development Party in Turkey} Ergun Özbudun

If one of the most interesting characteristics of the Turkish party system in the 1990s was the rapid rise of political Islam under the banner of the Welfare Party, an equally, perhaps even more, noteworthy development in the early 2000s is its transformation under the Justice and Development Party (AKP) leadership into a moderate conservative democratic party. Various aspects of this transformation are the central focus of this work. The AKP is compared with the earlier Islamist parties in terms of ideology, organization, competitive strategy, and government performance.

Keywords: Turkish Party System; Justice and Development Party; Political Islam; Party Change

\section{Introduction}

If one of the most interesting characteristics of the Turkish party system in the 1990s was the rapid rise of political Islam under the banner of the Welfare Party (RP), an equally, perhaps, even more, noteworthy development in the early 2000s is its transformation under the Justice and Development Party (Adalet ve Kalkınma Partisi, AKP) leadership into a moderate conservative democratic party. The AKP won the 3 November 2002 parliamentary elections with 34.3 per cent of the vote and almost twothirds (363) of the assembly seats. Various aspects of this transformation will be the central focus of this essay. In the first section dealing with recent party history, the AKP will be studied in the context of the earlier Islamist parties, since the AKP itself is a very new party (established on 14 August 2001) and only such comparison can give an idea of the extent of this transformation. In the second section, party values and programme will be examined in greater detail, especially in comparison with those of the previous Islamist parties. It will be argued that the AKP has less in common with 
them than with the mainstream centre-right parties in Turkey. In the following section on party organization, again some comparisons will be made with the predecessor parties. In the section on competitive strategy and campaign tactics, the emphasis will be on the AKP's dilemma between maintaining the loyalty of its religious-conservative voters and keeping its appeal to a much broader centre-right sector of the Turkish electorate.

\section{Recent Party History}

In the history of the Turkish Republic, the first party with clear Islamist credentials was the National Order Party (MNP) established in 1970 under the leadership of Necmettin Erbakan, an independent deputy from Konya and a former professor at Istanbul Technical University. The party was closed down by the constitutional court following the military intervention of 1971, and was replaced by the National Salvation Party (MSP) in 1973 under the same leadership. The MSP remained a medium-size party in the 1970s and its national vote share never exceeded 12 per cent. However, it played an important role in coalition politics between 1973 and 1980, because of the peculiarities of the parliamentary arithmetic. Mr Erbakan served as deputy prime minister in both the Bülent Ecevit (centre-left) and Süleyman Demirel (centre-right) governments. ${ }^{1}$ The party was closed down again after the military intervention of 1980, and reorganized in 1983 under the name of the Welfare Party. After a modest restart in the local elections of 1984, its vote percentage rose to 7.2 in the 1987 national elections, and to 16.9 in 1991 (in alliance with the Nationalist Action Party and the Reformist Democracy Party). In the 1990s, the RP vote rose rapidly. In the 1994 local elections it captured the mayoralties of the two largest cities of Turkey (Istanbul and Ankara), as well as those of many other provincial centres, with over 19 per cent of the national vote. The 21.4 per cent of the national vote and 158 parliamentary seats it won in the December 1995 parliamentary elections represented the party's best national showing ever, making it the largest party in parliament (see Table 1).

Opinions vary about the nature of the challenge the RP represented. The party combined religious and nonreligious appeals, as seen in its emphasis on industrialization, social justice, honest government, and the restoration of Turkey's former grandeur. It is unclear whether the RP seriously intended to establish an Islamic state based on sharia (Islamic law) or would be satisfied with certain, mostly symbolic, Islamic acts in some areas of social life. The party's statements on these issues were vague and contradictory, lending themselves to more than a single interpretation.

Ambivalence also marked the RP's views toward democracy. The party's 1995 campaign platform called the present Turkish system a 'fraud', a 'guided democracy', and a 'dark-room regime' and announced the RP's intention to establish a 'real pluralistic democracy'. However, apart from promises to enhance freedom of conscience and to make greater use of referenda and popular councils, real democracy was never defined. In the party's view, freedom of conscience implied the 'right to live 
Table 1 Percentage of Votes of Islamist Parties in Parliamentary and General Local Elections (1973-2004)

\begin{tabular}{llr}
\hline Year & Party & Votes (\%) \\
\hline 1973 & (parliamentary): National Salvation Party (MSP) & 11.8 \\
1977 & (parliamentary): MSP & 8.6 \\
1984 & (local): Welfare Party (RP) & 4.4 \\
1987 & (parliamentary): RP & 7.2 \\
1989 & (local): RP & 9.8 \\
1991 & (parliamentary): RP (in coalition with the MHP and IDP) & 16.9 \\
1994 & (local): RP & 19.1 \\
1995 & (parliamentary): RP & 21.4 \\
1999 & (parliamentary): Virtue Party (FP) & 15.4 \\
2002 & (parliamentary): Justice and Development Party (AKP) & 34.3 \\
2004 & (local): AKP & 41.2 \\
\hline
\end{tabular}

*MHP stands for the Nationalist Action Party and IDP for the Reformist Democracy Party.

according to one's beliefs', a concept bound to create conflicts with Turkey's secular legal system.

The RP prudently refrained from challenging the basic premises of democracy and stated that elections constitute the only route to political power. One gets the impression, however, that the version of democracy it envisaged was more majoritarian than liberal or pluralistic. Erbakan and other party spokesmen stated that democracy was not the aim, but only a means; the aim was to establish the 'order of happiness', apparently a reference to the time of Prophet Muhammad, usually called the age of happiness (asr-ı saadet) in Islamic writings. Ruşen Çakır, a leading Turkish student of the RP, concluded that 'the RP is neither pro-Sharia nor democrat, because it is both pro-Sharia and democrat in its own way' (Çakır 1994, pp. 128-129). ${ }^{2}$

In the field of the economy, the RP proposed an Islamic-inspired 'just order' (adil dïzen) that it conceived of as a third way, different from and superior to both capitalism and socialism. Although the party claimed the just order was the true private enterprise regime', its implementation — even if it were possible-would have required heavy state controls. In foreign policy, the RP advocated an essentially thirdworldist policy, much closer relations with other Islamic countries, an Islamic common market, an Islamic NATO, an Islamic UNESCO, and an Islamic monetary unit. The RP's foreign policy discourse often contained anti-American, anti-European, anti-Zionist, and even anti-Semitic elements. The RP was strongly opposed to Turkey's accession to the European Union, which it described as a 'Christian club'.

The RP came to power in 1996 in coalition with the centre-right True Path Party (DYP) under the premiership of Mr Erbakan. The RP-DYP government's policies soon created serious frictions with the military, the secular state establishment, and most of the leading civil society organizations. The process that started with the dramatic meeting of 28 February 1997 of the National Security Council, at which military commanders strongly criticized the government and demanded strict measures against 
religious reaction, led to the resignation of the Erbakan government, and eventually to the prohibition of the RP by the Constitutional Court in 1998, for having violated the secularist principles of the Turkish constitution. The Constitutional Court's decision was also upheld by the European Court of Human Rights.

The RP was replaced by the Virtue Party (FP) led by Recai Kutan, Erbakan's close associate. Erbakan himself had been barred from politics for five years by the decision of the Constitutional Court. However, the Constitutional Court also closed down the FP in 2001, which led to a split in the Islamist ranks. The group that called themselves 'innovationists' (yenilikçiler) established the AKP under the leadership of Recep Tayyip Erdoğan, former mayor of Istanbul, on 14 August 2001, while the 'traditionalists' (gelenekçiler) organized under the name of the Felicity Party (SP) led by Recai Kutan, the former leader of the dissolved FP. In the 3 November 2002 parliamentary elections, the AKP came to power with 34.3 per cent of the vote and almost two-thirds of parliamentary seats, while the SP remained a minor party with only 2.5 per cent of the vote. The subsequent AKP government was the first single-party government since 1991, when the Motherland Party (ANAP) lost its parliamentary majority.

Analyses of the voter base of the AKP demonstrated that the party is not a direct descendant of any of the older parties; nor do the party leaders claim such lineage. A 2002 pre-election survey showed that only 27.4 per cent of the AKP voters had voted for the FP in 1999; a surprisingly high 21.9 per cent had voted for the ultra-nationalist Nationalist Action Party (MHP), 9.2 per cent for the centre-right ANAP, 7.3 per cent for the centre-right True Path Party (DYP), and 6.9 per cent for the centre-left Democratic Left Party (DSP). Similarly, 57 per cent of former FP voters, 30.5 per cent of former MHP voters, 16.8 per cent of former DYP voters, 16.7 per cent of former ANAP voters, and 10.8 per cent of former DSP voters expressed their intention to vote for the AKP in the 2002 elections (Foundation for Social, Economic and Political Research [TÜSES] 2002, pp. 70-71). These findings are corroborated by those of two other survey research organizations, ANAR and SAM, in surveys carried out in October 2002. ${ }^{3}$ Thus, the AKP seems to have received substantial support from the former voters of the two centre-right parties (ANAP and DYP) and those of the ultranationalist MHP, in addition to more than half of the former Islamist FP voters. The rest of the latter seem to have remained loyal to the Erbakan tradition now represented by the SP, which received only 2.5 per cent of the vote in the 2002 elections. Surprisingly, some 10 per cent of former voters of the leftist DSP also indicated their intention to vote for the AKP.

On the basis of these findings, it may be concluded that the AKP appears to have successfully rebuilt the Özal ANAP coalition, bringing together former centre-right voters, moderate Islamists, moderate nationalists, and even a certain segment of the former centre-left. Indeed, ANAP maintained this coalition for two legislative terms (1983-91), when it formed a single-party government and played a vital role in developing a free market economy open to international competition and in normalizing politics following a period (1980-83) of stern military rule. The ANAP coalition started to weaken in the 1990s for reasons beyond the scope of this work, 
and today the party is reduced to a clearly minor party status. Sociologically speaking, the AKP coalition is based on the support of much of the rural population, artisans and small traders in the cities, urban slum-dwellers, and the rapidly rising Islamist bourgeoisie. A Turkish scholar describes the AKP as 'the political representative of the new middle class' comprising provincial artisans and traders, small and mid-range entrepreneurs, and young business executives, although he adds that the AKP also received votes from a good portion of the working class (İnsel 2003, pp. 297-299). Obviously, this is a rather heterogeneous coalition, socially and politically. Only time will tell if the AKP will be able to maintain it in the long run, a formidable task which the ANAP failed to accomplish. If the AKP fails in this task, it may well follow the route of the ANAP to become a minor party based essentially on Islamist votes.

The ideological differences between the AKP and its predecessor Islamist parties will be dealt with in the next section. Suffice it to say here that the differences are real and profound. Such a radical transformation may be due to a number of factors. However, in explaining it, one should not neglect the effect of the '28 February process' and the consequent prohibition of the RP and the FP by the Constitutional Court. Indeed, the Turkish constitution is strongly committed to secularism, and parties that are found to be violating these secularist principles run the serious risk of being closed down. As a result of the closure of the RP and FP, a group of former Islamist politicians seems to have reached the conclusion that challenging the secular state in Turkey is a dead-end. The AKP represents the transformation of political Islam into a moderate conservative democratic party, reconciled to the secular principles of the constitution.

\section{The AKP Programme and Values}

The AKP's constitution describes the Republic 'as the most important acquisition of the Turkish nation' and asserts that 'the will of the nation is the only determinant power'. The party 'considers the will of the nation, the rule of law, reason, science, experience, democracy, the fundamental rights and freedoms, and morality as the main references of its conception of government'. The AKP 'acknowledges and respects all the birthrights of people, such as having different beliefs, ideas, races, languages, the right of expression, the right of association, and the right to live. It considers that diversity is not (a source of) differentiation, but our cultural richness that reinforces our solidarity.' The AKP believes that national will can be sovereign only when political rights are freely exercised, and, in turn, free exercise of political rights can only be realized in a pluralist and participatory democratic society. The AKP emphasizes the freedom of expression for everybody and the right to live according to one's beliefs. The state should not favour or oppose any belief or thought, and the guarantee of this understanding are the constitutional principles regarding secularism and equality before the law. In the field of the economy, the AKP aims to establish a free market economy with all its institutions and rules and recognizes the role of the state in the economy only in a regulatory and supervisory capacity (AKP 2002b, art. 4). 
Similarly, the AKP's 'Development and Democratization Programme' strongly emphasizes democracy, human rights, and the rule of law. Thus, it is asserted that 'freedoms constitute the foundation of democracy' and that respect for individual rights and freedoms is the basic condition for the establishment of social peace and well-being, as well as for the acceptance of a democratic political regime by the people. It promises to bring human rights standards in Turkey to the level envisaged by the Universal Declaration of Human Rights, the European Convention of Human Rights, the Paris Charter, and the Helsinki Final Act. It specifically mentions freedom of thought and expression, the right to information, the right to seek justice, and the right to a fair trial. The AKP's notion of democracy is more pluralistic than majoritarian. The importance of tolerance, dialogue, and respect for minority rights is constantly emphasized.

The AKP programme much more clearly supports secularism than did the former Islamist parties. Thus, it is stated that while religion is one of the most important institutions of humanity, secularism is a sine qua non condition for democracy, and the guarantee of freedom of religion and conscience. 'Secularism allows people of all religions and beliefs to practise their religion in peace, to express their religious convictions and to live accordingly, but also allows people with no religious beliefs to organize their lives in their own direction. Therefore, secularism is a principle of freedom and social peace' (AKP 2002a). Last but not least, the AKP regards Atatürk's principles and reforms as the most important vehicle for raising Turkish society above the level of contemporary civilization and considers them an element of social peace.

The programme's section on the economy declares the party's commitment to a functioning free market economy with all its rules and institutions, and aims to limit the state's role in the economy to a merely regulatory and supervisory function. The programme supports privatization and the encouragement of foreign investment in Turkey.

On foreign policy, the programme emphasizes the importance of Turkey's ties with the United States, European countries and the European Union, NATO, and the Central Asian Turkic republics. The programme also states that the AKP attributes a special importance to Turkey's relations with Islamic countries (AKP 2002a).

On the basis of its programme, the AKP seems hardly distinguishable from a liberal or conservative democratic party. Although the party describes itself as 'conservative democrat', there is very little emphasis on conservative values in the programme, except for the passages supporting family values and emphasizing the need to strengthen the family. The party's views on conservative democracy are more clearly elaborated in a document entitled Conservative Democracy (Akdoğan 2003), prepared and distributed by the central headquarters of the party. In his introduction to this document, the party leader Recep Tayyip Erdoğan states the AKP's opposition to the notion of 'political community which radicalizes politics', a clear reference to the practice of the older Islamist parties. Erdoğan also criticizes a second type of political party which he terms 'political corporations', namely parties that lack any political principles and aim at the distribution of public rent among its supporters. Erdoğan 
claims that the AKP has become 'the undisputable single force of the centre-right'. He also made it clear that the AKP's understanding of conservatism was not against change, but that it advocated change 'in the sense of development and progress'. 'The AKP emphasizes a modern conservatism open to innovation, in place of the conservatism of the past which was built on the status quo. The AKP advocates change based on an evolutionary, gradual, and natural societal transformation. ${ }^{34}$

The AKP's conservatism can best be described as an attitude in favour of natural and evolutionary change, and a posture against social engineering. Erdoğan makes this clear when he states that 'all efforts that impose or order certain principles and aim at a homogeneous society, or are based on social engineering are obstacles to a healthy democratic system ... Our identity as conservative democrats makes us oppose all kinds of social and political engineering' (AKP 2004a, p. 9). In his speech at the first general congress of the AKP on 12 October 2003, Erdoğan also gave certain clues as to the party's understanding of conservative democracy. He claimed that the AKP substituted a notion of politics based on compromise and reconciliation in place of a politics based on conflict, and described the AKP's democratic conservatism as representing the 'societal centre'. Thus, he sees democratic conservatism as a means of bridging the gap between the state and society, to unite the centre with the periphery. In his view, there is no conflict between republican and democratic values, and he points to Kemal Atatürk as the source of republican values, which should remain 'as our firmest foundations'. Finally, he repudiates religious, ethnic, and regional nationalism as the 'red lines' of the AKP (AKP 2004b, pp. 4-7).

It may be argued that party statutes, programmes, and other official documents are of limited value in understanding the true nature of a party, since it is always possible that such documents may hide its real intentions. Thus, some radical secularists in Turkey view the AKP with suspicion and suspect that the party's real intention is to establish an Islamic republic. However, the party's performance in government does not lend support to such gloomy predictions. The AKP government has so far followed moderate policies, accomplished significant constitutional and legislative reforms to raise democratic standards in Turkey to the level required by the Copenhagen criteria, accepted Turkey's accession to the EU as one of its most important priorities, and prudently refrained from policies (such as lifting the ban on wearing headscarves at universities) that would have caused frictions with the secular state establishment. During its three years in power, the AKP majority in parliament adopted two constitutional amendments (those of 2002 and 2004) and six 'harmonization packages' designed to harmonize Turkish legislation with EU standards. Particularly significant were the constitutional amendments of 2004 which, among other things, repealed the death penalty for all crimes, abolished the controversial state security courts, recognized the supremacy of international agreements over domestic legislation in the field of human rights, and gave a stronger wording to the article on gender equality. Furthermore, the AKP sought and obtained the support of the major opposition party, the Republican People's Party (CHP), for both the constitutional amendments and the harmonization packages (Özbudun \& Yazıcı 2004). It is a well-known fact that Turkish 
voters do not normally base their voting choices on parties' abstract ideologies and political identities, but mostly on their performance, image, and the personal characteristics of their leaders. In this sense, the AKP's conservative democrat image may well be intended more for the consumption of intellectuals, the state establishment, and foreign policy-makers than as an ideology that will effectively mobilize its voter base (Fedayi 2004; Yıldız 2004, p. 46). A Turkish political scientist describes the AKP as 'Islamic in name, liberal in practice, democrat in attitude, and westernist in direction. ${ }^{5}$

\section{Party Organization}

The Turkish political parties law, adopted in 1983 by the then military regime, is probably the most detailed of its kind in Europe. It contains not only party prohibitions, but also extremely detailed regulations on party organization, registration, membership, nominations, discipline, and party finance. Consequently, all Turkish parties have very similar organizational structures imposed upon them by the law. Thus, at all levels, the presidents and executive committees are elected by their respective congresses composed of delegates chosen by registered members. The central organs are the grand (general) congress, the party president (leader), the central executive committee, and the central disciplinary committee. The grand congress is the highest decision-making body; it elects the party president, the central executive committee, and the central disciplinary committee. Local organizations consist of province, sub-province (county), and municipality organizations (all settlements with a minimum of 2,000 inhabitants are entitled to have a municipal organization). The law does not permit party organization below the sub-province or municipality level. There are therefore no legal organizational units at the village or urban neighbourhood level. However, parties usually get around this prohibition by appointing informal party representatives, or even representative committees at the village or urban neighbourhood levels. At the province and sub-province levels, party presidents and the executive committees are elected by the province and sub-province congresses, respectively.

As regards the nomination of parliamentary candidates, article 37 of the law leaves the choice of candidate selection method to party statutes. However, if a party decides to hold primary elections to select its candidates, such elections are to be held under judicial supervision. The current practice in almost all parties is to have candidates selected by the central executive committee, where the influence of the party leader is paramount. The political parties law also contains certain provisions concerning the parties' parliamentary groups. Under article 27 of the law, parliamentary groups may take binding group decisions. Article 28 stipulates that the decisions concerning a vote of confidence or no confidence in a minister or the council of ministers can be taken only by the party's parliamentary group. Thus, although legally speaking the parties' central executive committees do not have the power to take binding decisions on matters of vote of confidence, in practice both organs work together closely and both are dominated to a large extent by the party leader. The AKP is no exception in this regard. 
The AKP's organizational structure closely conforms to this overall design (AKP $2002 \mathrm{~b}$ ). The party's highest decision-making body is the grand congress, which is composed of delegates chosen by provincial congresses and ex officio delegates. Ex officio delegates comprise the party leader, members of the central decision-making and executive committee, the president and members of the central disciplinary committee, founding members, and ministers and deputies who are party members (AKP 2002b, art. 62). The congress is authorized to elect the party leader, the central decision-making and executive committee, the central disciplinary committee, and the members of the intra-party democracy arbitration committee. It has also the power to change the party's statute and programme, to take binding or non-binding decisions on public issues and party policies, and to decide on the dissolution of the party (AKP 2002b, art. 61). The grand congress meets not more often than every two years, and at least every three years (AKP 2002b, art. 63).

The central decision-making and executive committee is the second-highest authority in the party. It is composed of 50 members (and 25 substitutes) elected by the grand congress by secret vote. It is chaired by the party leader and meets at least once a month (AKP 2002b, art. 73). It is authorized to make decisions on party policies and all organizational matters including decisions to form a government or to leave a coalition government (AKP 2002b, art. 148). However, as in all Turkish political parties, the party leader exercises a paramount influence within this committee. As regards party leadership, the AKP's statute introduces a novelty by limiting the tenure of the leader to four ordinary terms (that is, 12 years at most) (AKP 2002b, art. 75). Within the central decision-making and executive committee, a smaller body called the central executive committee ensures the daily functioning of the party. It is composed of the party president, vice-presidents (at the moment there are 11 vice-presidents), the secretarygeneral, and the president and the vice-president of the party parliamentary group (AKP 2002b, arts 79-82). It may be concluded that, together with the party leader, the central executive committee is the most powerful body in the party. Theoretically speaking, one may expect frictions between the central executive committee and the council of ministers when the party is in power. There are no legal obstacles to ministers also serving as members of the central executive committee. In practice, however, these posts are generally separated. Bearing in mind the dominant influence of the party leader, the chances for such frictions developing between the two bodies are negligible.

Another novelty of the AKP's statute which is not found in other parties is the establishment of intra-party democracy and arbitration committees at the central and provincial levels. These committees are authorized to find amicable settlements to conflicts among party members or party organs arising out of their party functions (AKP 2002b, arts 98-102).

At the local level, the AKP's organization consists of municipal, sub-provincial, and provincial congresses and executive committees. The smallest unit is the municipal organization, consisting of the municipal congress, the municipal president, and the municipal executive committee, all elected by the municipal congress (AKP 2002b, arts 21-27). Below the municipal level, however, informal party representatives or 
representative committees can be appointed at the urban neighbourhood, village, and polling district levels. Polling district committees are composed of one president and nine members, three of whom are from the main party organization, and three each from the women's and youth organizations. Polling district presidents also serve as election observers on the voting day. In addition, provincial executive committees may establish electoral committees to conduct electoral activities within the constituency (AKP 2002b, art. 19). Sub-provincial and provincial party organizations are organized along the same lines, consisting of a delegates' congress, a president, and an executive committee elected by the congress. The AKP, like most of the other Turkish parties, also has youth and women's organizations at all organizational levels. Again as with most other Turkish political parties, the AKP has a highly centralized and hierarchical organization. This is partly a function of the political parties law, and partly one of Turkish political culture, which encourages strong central and personalistic leadership. Thus, although local organizations cannot be dismissed as mere appendages of limited usefulness, they are largely dominated by the central bodies.

As was pointed out above, this organizational model, largely imposed by the political parties law, is more or less standard for all Turkish political parties. What distinguishes one party from the others is, therefore, not its formal organizational features, but its organizational culture. I have argued elsewhere that most Turkish political parties combine certain characteristics of cadre, catch-all, and cartel parties, with strong clientelistic features. The only Turkish political party that deviated from this pattern and approached the characteristics of a mass party was the RP, one of the predecessors of the AKP. What distinguished the RP from the others was the strong ideological and emotional attachment of its members (a 'devotee party' in Duverger's terminology) and the party's intense efforts at indoctrination, mobilization, and intraparty education (Özbudun 2000, pp. 92-3). A pertinent question is whether the AKP maintains the same organizational culture. The AKP's vice-president, interviewed by the author, indicated that this was not the case and that the AKP members do not have quite the same ideological and emotional motivations. In any case, according to his estimate, only $12-15$ per cent of the AKP members were previously RP or FP members. ${ }^{6}$

If one criterion for a mass party is the number of members, the AKP can still be said to be approaching the mass party model. As of mid-July 2005, the AKP reportedly had 2,362,857 members, an approximately 21.9 per cent member/AKP voter ratio and about 5.5 per cent member/registered voters ratio. This is a very high membership (members/voters) ratio compared with most European standards. Earlier research had shown, however, that membership ratio is generally high for all Turkish parties. Thus, a 1996 survey had found that 12.1 per cent of all voters were members of a political party (TÜSES 1996, p. 93). Such inflated figures may raise doubts about their accuracy. However, nowadays party membership registers are also kept by the prosecutor general of the Court of Cassation, which should increase their reliability. Another explanation may lie in the clientelistic nature of Turkish political parties. A majority of party members see their membership as a means to obtain 
personal, sometimes quite small, sometimes very substantial, benefits from their parties, particularly when they happen to be in government. A good example is the ANAP, which was the government party between 1983 and 1991, and still seems to have more than six million registered members, although it received only five per cent of the vote in the 2002 elections (about one-fifth of the number of its registered members). A third factor is the efforts by the local party officials to register their friends and members of families in order to augment their delegate base. But perhaps a more convincing explanation is that most Turkish party members do not clearly distinguish between being a party member and being a mere supporter. Party membership in Turkey entails certain rights, but almost no obligations to the party, including paying membership dues. Thus, in all Turkish parties only a very small proportion of party income comes from membership dues, and the AKP is no exception in this regard.

Still, the AKP's membership figure of more than two million does not seem to be unrealistic. Party officials state that about 300,000 of them perform some active party duty, such as being deputies, mayors, city councillors, members of the provincial general assemblies, members of the executive committees at the central, provincial, sub-provincial, and municipal levels; village, neighbourhood, and polling district representatives; members of the executive committees of women's and youth organizations at all levels, etc. This figure indicates a highly active and vibrant party life, and it does not include ordinary militants who have no official public or party positions.

Another characteristic that brings the AKP close to a mass party model is the emphasis given to intra-party education and indoctrination. For example, in 2005 two-day education seminars were organized in 17 different localities, and a national education seminar was convened in Ankara in September 2005, in which three members from each province participated. Its purpose was to educate the educators, and the ultimate aim was to educate 300,000 active-duty members. The seminars addressed such subjects as party organization, election processes, party ideology, economy, and foreign policy. In addition, during election times, seminars on electoral matters are organized for polling station observers.

Communications between the central bodies and the local organizations seem to be highly effective. The party officials claim that the AKP makes the most efficient use of computer facilities of all Turkish parties. A good example of the use of computers, as well as of the AKP's efforts to maintain close contacts with its members and supporters, is the AKP communication centre (Akim). The centre receives complaints and requests from members and non-members, on party and governmental matters, processes them, transmits them to relevant authorities, and informs the petitioners of the outcome. The fully computerized Akim has been functioning for two-and-a-half years, and has so far received some 217,000 applications; the monthly average is about 9,000-11,000 applications, some 60 per cent of which are processed and answered. Akim centres are also established in all 81 provinces, and in some of the major sub-provinces. 


\section{Competitive Strategy and Campaign Politics}

The AKP's main competitive strategy seems to be based on capturing and maintaining the centre-right votes. Centre-right parties have always dominated Turkish politics since the transition to a multi-party system in 1946-50. The erosion of the two oncepowerful centre-right parties (ANAP and DYP) for a number of reasons gave the AKP a golden opportunity to capture that space. That explains the party leaders' statements that the AKP has become the singular force on the centre-right and that it represents the societal centre. The AKP leadership seems to have realistically concluded that relying on hard-core Islamist votes would never make them a majority party. Certainly, the party's 34.3 per cent vote share in the parliamentary elections of 2002 and its even better showing in the general local elections of 2004 (over 41 per cent) far exceed the potential of the earlier Islamist parties. The AKP leadership gives every indication that it will follow the same competitive strategy in the coming elections. In this race, its main competitors would be the ANAP and the DYP and the ultranationalist MHP. Given the extreme volatility of Turkish voters, it will not be an easy task for the AKP to maintain the dominant position it now enjoys on the centre-right.

As in most other democratic countries, election campaigns in Turkey have centred around the personality and personal characteristics of the party leader in recent years. This is particularly the case for the AKP, where Erdoğan's powerful charismatic personality and 'man of the people' image contributed substantially to the party's electoral success. Another recent general trend is the increasing professionalization of electoral campaigns and the growing importance of television. Nowadays, each party conducts its electoral campaign with the help of professional public relations experts and pollsters. The RP was probably the only Turkish party in modern times to appreciate the value of traditional door-to-door canvassing methods while not neglecting more modern campaign techniques. Reliance on such face-to-face personal contacts seems to have paid off handsomely in the RP case.

Like all other parties, the AKP attributes special importance to the organization of electoral campaigns. A booklet called Guide to Elections prepared by the central office of the party is intended to inform all campaign workers of the intricacies of the highly detailed Turkish election laws (AKP 2002c). Another guide prepared for the 2004 local elections gives more practical advice on how to organize the campaign. Thus, it is emphasized that only the standard campaign materials prepared by the central office of the party can be used by local organizations, hinting at the highly centralized character of the campaign. Campaign workers are also advised to wear proper attire, to display a warm and friendly attitude toward voters, to refrain from unnecessary debates with voters, to refrain from demeaning other parties or candidates, to employ different discourses for different categories of voters, and to maintain close contacts with local non-governmental organizations. Campaign workers are warned against expressing their own personal opinions instead of those of the party (AKP 2004c). In addition to the activities of local campaign workers, the party leadership, particularly Mr Erdoğan, was very active both in the 2002 parliamentary and the 2004 local election campaigns. 


\section{Conclusion}

As stated at the outset, the transformation of Turkish political Islam, once considered a serious threat to the stability of democracy, into a moderate conservative democratic party is a development of paramount importance in Turkish politics. This development can be seen as a significant step toward bridging the age-old deep cleavage between secularists and Islamists, thus contributing to the consolidation of democracy in Turkey. ${ }^{7}$ The success or failure of the AKP experience is likely to have repercussions beyond Turkey's borders and in the entire Islamic world. This radical change from the practice of older Islamist parties seems to have been a function of the realization by a wing of the former Islamist parties (RP and FP) that challenging the secular character of the state in Turkey would be futile. Thus, the formation of the AKP was triggered by the closure of the FP by the Constitutional Court. Furthermore, the leaders of the 'innovationist' faction realized that relying essentially on hard-core Islamist votes would condemn the party forever to a minority (if not a minor party) status-hence, the AKP's effort to broaden its appeal to the centre-right of the political spectrum. This new approach has contributed significantly to diminishing the importance of the secularist-Islamist cleavage in Turkish politics.

The most serious risk facing the AKP stems from its coalitional character. Despite strong disclaimers from the party leadership, there is little doubt about this coalitional nature. The AKP brings together moderate Islamists, moderate nationalists, secular but socially conservative centre-right voters, and a sizable number of liberal intellectuals. The similarity to Turgut Özal's ANAP coalition is striking. However, the ANAP was not able to maintain this coalition for a long time, and today it has been reduced to a minor party. It is not certain that the AKP will succeed where the ANAP failed. A second danger is the extreme volatility of Turkish voters, who generally base their voting decisions on short-term calculations of gains and losses. Turkish parties generally lack deep and lasting roots in society, and their performance in government becomes the main criterion in voters' choice. It should be borne in mind that none of the three parties that formed a coalition government between 1999 and 2002 is now represented in parliament. A third danger may arise from Erdoğan's plans, if he so decides, to become the president of the Republic in 2007, in which case he will have to leave the party leadership and resign from his party. His powerful charismatic authority has certainly been an important factor that has kept together the disparate elements within the AKP. It is not certain that a new leader will have the same kind of moral authority. A fourth danger may arise if Turkey's EU accession negotiations are interrupted or fail to produce the expected results. This may lead to ultra-nationalist and isolationist reactions and may put the AKP into a difficult corner as the party most strongly associated with the objective of full EU membership. In short, there are still many unknowns. What is certain, however, is that the AKP's performance will continue to have profound implications for the future of Turkish politics. 


\section{Notes}

[1] On the MSP period see Landau (1976); Toprak (1981); Sarıbay (1985); and Özbudun (1987).

[2] These paragraphs on the RP draw on my book (Özbudun 2000, pp. 87-88).

[3] Akyol (2002). See also Esmer (2002): Esmer estimates that a quarter of the former DSP voters voted for the AKP in 2002.

[4] Akdoğan (2003). Quotations from Erdoğan's 'Introduction' are from the enlarged version of the document on the website of the AKP: < www.AKParti.org.tr/Muhafaz.doc > ; Erdoğan's views are also repeated in AKP (2004a, pp. 1-12).

[5] Ali Yaşar Sarıbay, 'AKP Kimliksizliğe Mahkum' [The AKP is bound to lack an identity], quoted by Yild1z (2004, p. 47).

[6] I gratefully acknowledge the information provided by Mr Dengir Mir Mehmet Firat, VicePresident of the AKP, in an interview that took place on 13 July 2005. The information presented here is based on this interview unless indicated otherwise.

[7] Several years ago, I described the rise of Islamic fundamentalism and ethnic Kurdish nationalism as the chief obstacles to the consolidation of democracy. See Özbudun (2000, pp. 141-145).

\section{References}

Akdoğan, Y. (2003) Muhafazakar Demokrasi [Conservative Democracy], AK Parti Yayınları, Ankara.

AKP (2002a) AK Parti Kalkınma ve Demokratiklesme Program [The AKP Development and Democratization Program], AK Parti Yayınları, Ankara.

AKP (2002b) AK Parti Tüzüğ̈̈ [The Constitution of the AKP], AK Parti Yayınları, Ankara.

AKP (2002c) Seçim Rehberi [Guide to Elections], AK Parti Yayınları, Ankara.

AKP (2004a) International Symposium on Conservatism and Democracy, AK Parti Publication, Ankara.

AKP (2004b) AK Parti 1. Olağan Büyük Kongresi, Genel Başkan R.Tayyip Erdoğan'in Konuşması [The First Regular Grand Congress of the AKP, the Speech by the Party Chairman R. Tayyip Erdogan], AK Parti Yayınları, Ankara.

AKP (2004c) 28 Mart 2004 Yerel Seçim Kilavuzu [Guide to the Local Elections of 28 March 2004], AK Parti Yayınları, Ankara.

Akyol, T. (2002) 'AKP'nin Arkasinda Ne Var?' [What is behind the AKP?], Milliyet, 19 October.

Çakır, R. (1994) Ne Şeriat, Ne Demokrasi: Refah Partisini Anlamak [Neither the Sharia nor Democracy: Understanding the Welfare Party], Metis, Istanbul.

Esmer, Y. (2002) '3 Kasım Analizi' [The Analysis of 3 November], Milliyet, 18 November.

Fedayi, C. (2004) 'AKP’nin Siyasal Kimliği Üzerine: Kimlik Arkadan Gelsin' [On the political identity of the AKP: let identity come from behind], Muhafazakar Düşünce, vol. 1, no. 1, pp. 149-163.

İnsel, A. (2003) 'The AKP and normalizing democracy in Turkey', South Atlantic Quarterly, vol. 102, no. $2-3$, pp. $293-308$.

Landau, J. M. (1976) 'The National Salvation Party in Turkey', Asian and African Studies, vol. 11, no. 1 , pp. 1-57.

Özbudun, E. (1987) 'Islam and politics in modern Turkey: the case of the National Salvation Party', in The Islamic Impulse, ed. B. Stowasser, Croom Helm, London, pp. 142-156.

Özbudun, E. (2000) Contemporary Turkish Politics: Challenges to Democratic Consolidation, Lynne Rienner, Boulder and London.

Özbudun, E \& Yazıc1, S (2004) Democratization Reforms in Turkey (1993-2004), TESEV, Istanbul.

Sarıbay, A. Y. (1985) Türkiye'de Modernleşme, Din ve Parti Politikası: MSP Örnek Olayi [Modernization, Religion, and Party Politics in Turkey: A Case Study of the MSP], Alan, Istanbul. 
Toprak, B. (1981) Islam and Political Development in Turkey, E. J. Brill, Leiden.

TÜSES (1996) Türkiye'de Siyasi Parti Seçmenlerinin Nitelikleri, Kimlikleri ve Eğilimleri [Characteristics, Identities, and Tendencies of Political Party Voters in Turkey], Ankara.

TÜSES. (2002) Türkiye'de Siyasi Partilerin Yandaş/Seçmen Profili (1994-2002) [The Supporter/Voter Profiles of Political Parties in Turkey], Istanbul.

Yıldız, A. (2004) 'AK Parti'nin 'Yeni Muhafazakar Demokratlığı' [The new conservative democracy of the AKP], Liberal Dusunce, vol. 9, no. 34, pp. 41-48. 